\title{
Complete genome sequence of the nitrogen-fixing bacterium Azospirillum humicireducens type strain SgZ- $5^{\top}$
}

\author{
Zhen Yu', Guiqin Yang ${ }^{1}$, Xiaoming Liu', Yueqiang Wang ${ }^{1}$, Li Zhuang ${ }^{2^{*}}$ and Shungui Zhou ${ }^{3}$
}

\begin{abstract}
The Azospirillum humicireducens strain SgZ-5 ${ }^{\top}$, belonging to the Order Rhodospirillales and the Family Rhodospirillaceae, was isolated from a microbial fuel cell inoculated with paddy soil. A previous work has shown that strain SgZ- $5^{\top}$ was able to fix atmospheric nitrogen involved in plant growth promotion. Here we present the complete genome of A. humicireducens SgZ- $5^{\top}$, which consists of a circular chromosome and six plasmids with the total genome size of $6,834,379 \mathrm{bp}$ and the average GC content of $67.55 \%$. Genome annotations predicted 5969 protein coding and 85 RNA genes including 14 rRNA and 67 tRNA genes. By genomic analysis, we identified a complete set of genes that is potentially involved in nitrogen fixation and its regulation. This genome also harbors numerous genes that are likely responsible for phytohormones production. We anticipate that the A. humicireducens SgZ- $5^{\top}$ genome will contribute insights into plant growth promoting properties of Azospirillum strains.
\end{abstract}

Keywords: Azospirillum humicireducens, Complete genome, Nitrogen fixation, PGPP

\section{Introduction}

Bacteria that live in the plant rhizosphere and possess a large array of potential mechanisms to enhance plant growth are considered as PGPR [1-3]. Azospirillum represents a well characterized genus of PGPR due to its capacity of fixing atmospheric nitrogen $[4,5]$. Although the exact contribution of Azospirillum to biological nitrogen fixation in plant growth promotion is debated [2], agricultural applications of the genus Azospirillum have been still developed $[6,7]$. Another main characteristic of Azospirillum proposed to explain plant growth promotion has been related to its ability to produce phytohormones $[8,9]$.

At present, there are 17 species within the genus Azospirillum [10], of which the nitrogen-fixing bacterium A. humicireducens SgZ-5 ${ }^{\mathrm{T}}$, the focus species of this study, was initially isolated from the anode biofilm of a MFC. A soil sample collected from paddy field in Guangzhou City, Guangdong Province, China $\left(23.18^{\circ} \mathrm{N} 113.36^{\circ} \mathrm{E}\right)$ was used as inoculating source of the MFC. In a previous

\footnotetext{
* Correspondence: zhuangli@jnu.edu.cn

${ }^{2}$ School of Environment, Guangdong Key Laboratory of Environmental

Pollution and Health, Jinan University, Guangzhou 510632, China

Full list of author information is available at the end of the article
}

report [11], the nitrogen-fixing capability of strain SgZ- $5^{\mathrm{T}}$ was confirmed by acetylene-reduction assay and identification of a nifH gene. Furthermore, this strain has the ability to grow under anaerobic conditions via the oxidation of various organic compounds coupled to the reduction of humus [11], showing its potential use in plant rhizosphere. Here, we describe the physiological features together with the whole genome sequence of A. humicireducens SgZ-5 ${ }^{\mathrm{T}}$.

\section{Organism information Classification and features}

A. humicireducens SgZ- $5^{\mathrm{T}}$ is a Gram-negative, facultative anaerobic, motile, spiral, straight to slightly curved rod-shaped bacterium (Fig. 1), belonging to the Order Rhodospirillales and the Family Rhodospirillaceae. The strain grew optimally in the conditions of $30{ }^{\circ} \mathrm{C}, \mathrm{pH} 7.2$, and $1 \% \mathrm{NaCl}$ [11]. On NA, strain SgZ- $5^{\mathrm{T}}$ formed creamcolored, round, smooth, convex and non-translucent colonies (Fig. 1). With AQDS as the sole terminal electron acceptor, strain $\mathrm{SgZ}-5^{\mathrm{T}}$ could utilize pyruvate, glucose and acetate as electron donors under anaerobic conditions [11]. Strain SgZ- $5^{\mathrm{T}}$ was able to use a range of carbon substrates including $\mathrm{N}$-Acetyl-glucosamine, citrate, D-ribose,

(c) The Author(s). 2018 Open Access This article is distributed under the terms of the Creative Commons Attribution 4.0 International License (http://creativecommons.org/licenses/by/4.0/), which permits unrestricted use, distribution, and reproduction in any medium, provided you give appropriate credit to the original author(s) and the source, provide a link to the Creative Commons license, and indicate if changes were made. The Creative Commons Public Domain Dedication waiver (http://creativecommons.org/publicdomain/zero/1.0/) applies to the data made available in this article, unless otherwise stated. 



Fig. 1 Images of the A. humicireducens SgZ-5 ${ }^{\top}$. a Colonies of the strain on NA agar plate, $\mathbf{b}$ light microscopy and $\mathbf{c}$ transmission electron microscopy of the strain

Table 1 Classification and general features of A. humicireducens SgZ-5 ${ }^{\top}$ according to the MIGS recommendations [16]

\begin{tabular}{|c|c|c|c|}
\hline MIGS ID & Property & Term & Evidence code \\
\hline & Current Classification & Domain Bacteria & TSA [22] \\
\hline & & Phylum Proteobacteria & TSA [33] \\
\hline & & Class Alphaproteobacteria & TSA [34] \\
\hline & & Order Rhodospirillales & TSA $[35,36]$ \\
\hline & & Family Rhodospirillaceae & TSA $[35,36]$ \\
\hline & & Genus Azospirillum & TSA $[37,38]$ \\
\hline & & Species Azospirillum humicireducens & TSA [11] \\
\hline & & Type strain SgZ-5=CCTCC AB 2012021=KACC 16605 & TSA [11] \\
\hline & Gram stain & Negative & TSA [11] \\
\hline & Cell shape & Spiral, straight to slightly curved rods & TSA [11] \\
\hline & Motility & Motile & TSA [11] \\
\hline & Sporulation & Nonsporulating & NSA \\
\hline & Temperature range & $25-37^{\circ} \mathrm{C}$ & TSA [11] \\
\hline & Optimum temperature & $30^{\circ} \mathrm{C}$ & TSA [11] \\
\hline & pH range; Optimum & $5.5-8.5 ; 7.2$ & TSA [11] \\
\hline & Carbon source & $\begin{array}{l}\text { Acetate, L-lactate, citrate, D-ribose, L-rhamnose, D-glucose, N-Acetyl-glucosamine, meso-inositol, } \\
\text { D-saccharose, D-maltose, suberic acid, malonate, L-serine, salicin, L-alanine, gluconate, glycogen, } \\
\text { 2-keto-gluconate, D-mannitol, D-melibiose, L-fucose, D-sorbierite, L-arabinose, L-histidine, } \\
\text { 3-hydroxy-butyric acid, 4-hydroxy-benzoic acid, L-proline, capric acid, adipic acid and malic acid }\end{array}$ & TSA [11] \\
\hline MIGS-6 & Habitat & Paddy soil & TSA [11] \\
\hline MIGS-6.3 & Salinity & $\mathrm{NaCl} 0-1 \%(w / v)$ & TSA [11] \\
\hline MIGS-22 & Oxygen requirement & Facultative anaerobic & TSA [11] \\
\hline MIGS-15 & Biotic relationship & Free living & NAS \\
\hline MIGS-14 & Pathogenicity & Not reported & \\
\hline MIGS-4 & Geographic location & Guangzhou City, Guangdong Province, China & NAS \\
\hline MIGS-5 & Sample collection time & Dec 2011 & NAS \\
\hline MIGS-4.1 & Latitude & $23.18^{\circ} \mathrm{N}$ & NAS \\
\hline MIGS-4.2 & Longitude & $113.36^{\circ} \mathrm{E}$ & NAS \\
\hline MIGS-4.3 & Depth & $0.1 \mathrm{~m}$ beneath the surface & NAS \\
\hline MIGS-4.4 & Altitude & $40 \mathrm{~m}$ & NAS \\
\hline
\end{tabular}

${ }^{a}$ Evidence code - IDA Inferred from direct assay, TAS Traceable author statement (i.e., a direct report exists in the literature), NAS Non-traceable author statement (i.e., not directly observed for the living, isolated sample, but based on a generally accepted property for the species, or anecdotal evidence). These evidence codes are from the Gene Ontology Project [39] 
meso-inositol, D-saccharose, D-maltose, L-rhamnose, suberic acid, malonate, acetate, L-serine, salicin, L-lactate, L-alanine, gluconate, 2-keto-gluconate, glycogen, D-mannitol, D-glucose, D-melibiose, L-fucose, D-sorbierite, L-arabinose, L-histidine, 3-hydroxy-butyric acid, 4-hydroxy-benzoic acid, L-proline, capric acid, adipic acid and malic acid [11] (Table 1).

A phylogenetic tree was constructed from aligning the $16 \mathrm{~S}$ rRNA gene sequences of strain $\mathrm{SgZ}-5^{\mathrm{T}}$ and type strains of the genus Azospirillum by MEGA 5 using the neighbour-joining method [12]. The phylogenetic position of strain $\mathrm{SgZ}-5^{\mathrm{T}}$ is shown in Fig. 2, where A. humicireducens can be grouped as a Azospirillum species, forms a distinct subclade together with $A$. lipoferum that are known as a biofertilizer widely used for agricultural production [13, 14]. The $16 \mathrm{~S}$ rRNA gene of strain $\mathrm{SgZ}-5^{\mathrm{T}}$ is $98 \%$ similar to that of $A$. lipoferum NCIMB $11861^{\mathrm{T}}$. Since nifH gene is highly conserved among nitrogen-fixing Proteobacteria [15], a nifH-based phylogenetic tree was constructed to identify the relationship of $A$. humicireducens to other species within the genus Azospirillum and related genus (Additional file 1). The phylogenetic reconstruction indicated the close relationship of the A. humicireducens SgZ-5 ${ }^{\mathrm{T}}$ nifH gene with that from Azospirillum sp. B510.

\section{Genome sequencing information}

\section{Genome project history}

A. humicireducens $\mathrm{SgZ}-5^{\mathrm{T}}$ was selected for genome sequencing on the basis of its biotechnological potential in
Table 2 Genome sequencing project information

\begin{tabular}{|c|c|c|}
\hline MIGS ID & Property & Term \\
\hline MIGS-31 & Finishing quality & Complete \\
\hline MIGS-28 & Libraries used & $\begin{array}{l}\text { Three libraries (a paired-end library } \\
\text { and two mate-pair libraries) }\end{array}$ \\
\hline MIGS-29 & Sequencing platforms & Illumina Hiseq 2500 \\
\hline MIGS-31.2 & Fold coverage & $259 \times$ \\
\hline MIGS-30 & Assemblers & SOAPdenovo 2.04 [17] \\
\hline \multirow[t]{6}{*}{ MIGS-32 } & Gene calling method & GeneMarkS+ [18] \\
\hline & Locus Tag & $\mathrm{A} 6 \mathrm{~A} 40$ \\
\hline & Genbank ID & СР015285.1, СР028902-СР028907 \\
\hline & $\begin{array}{l}\text { Genbank Date } \\
\text { of Release }\end{array}$ & April 18, 2018 \\
\hline & GOLD ID & Gp0150267 \\
\hline & Bioproject & PRJNA318554 \\
\hline \multirow[t]{2}{*}{ MIGS-13 } & $\begin{array}{l}\text { Source Material } \\
\text { Identifier }\end{array}$ & $\operatorname{SgZ}-5^{\top}$ \\
\hline & Project relevance & $\begin{array}{l}\text { Type strain, nitrogen fixation, } \\
\text { plant growth promotion }\end{array}$ \\
\hline
\end{tabular}

agricultural applications as a PGPR likely harboring multiple PGPP [11]. The complete genome sequences have been deposited at Gen-Bank/EMBL/DDBJ under the accession numbers CP015285.1, CP028902-CP028907. Project information is available from Genome Online database number Gp0150267 at Joint Genome Institute.

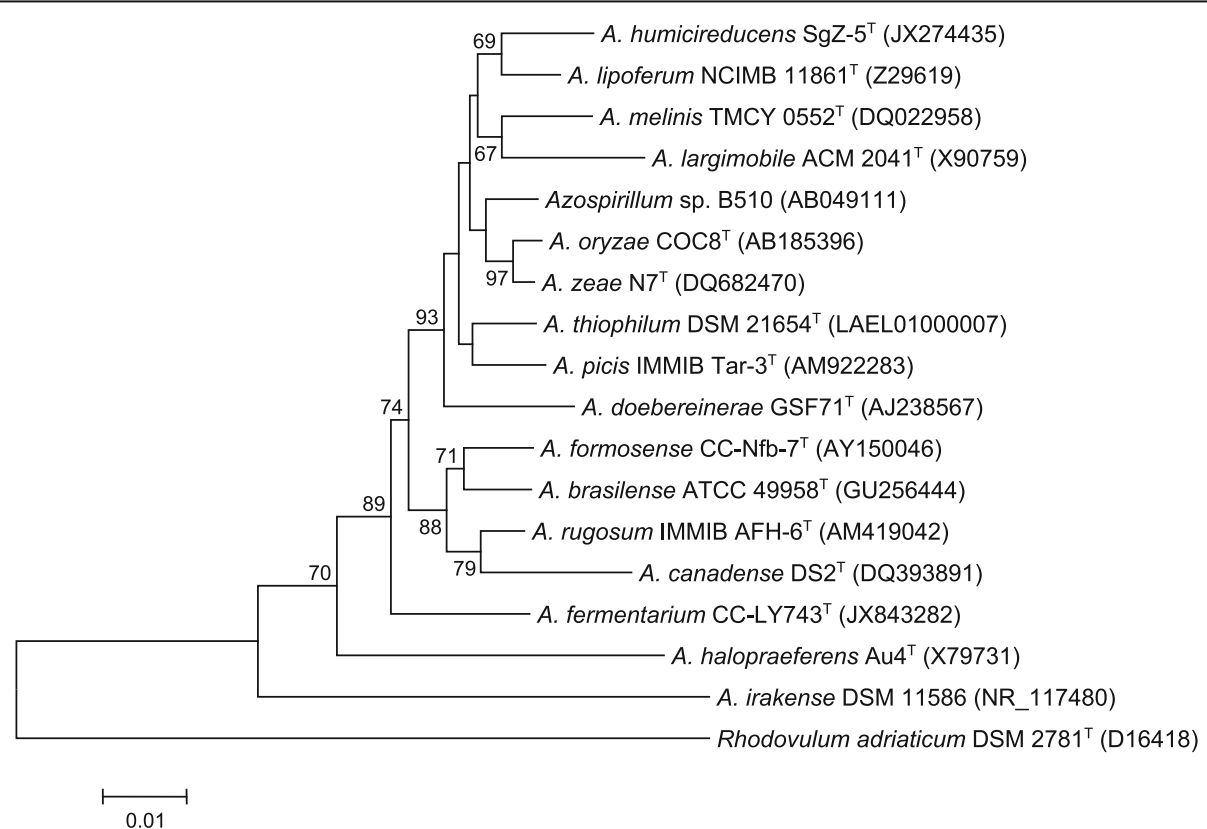

Fig. 2 Phylogenetic tree highlighting the position of A. humicireducens $\mathrm{SgZ}-5^{\top}$ relative to other type strains within the genus Azospirillum. The strains and their corresponding GenBank accession numbers of $16 \mathrm{~S}$ rRNA genes were indicated in parentheses. The sequences were aligned using Clustal W and the neighbor-joining tree was constructed based on kimura 2-paramenter distance model by using MEGA 5. Bootstrap values above $50 \%$ were obtained from 1000 bootstrap replications. Bar, 0.01 substitutions per nucleotide position. Rhodovulum adriaticum DSM $2781^{\top}$ was used as an outgroup 
In Table 2, we summarize the project information and its association with Minimum Information about a Genome Sequence (MIGS) [16].

\section{Growth conditions and genomic DNA preparation}

A. humicireducens $\mathrm{SgZ}-5^{\mathrm{T}}$ was routinely cultured in NB medium containing $\left(\mathrm{L}^{-1}\right) 5 \mathrm{~g}$ peptone, $3 \mathrm{~g}$ beef extract and $5 \mathrm{~g} \mathrm{NaCl}$ at $30{ }^{\circ} \mathrm{C}$. For genome sequencing, total genomic DNA was extracted from $10 \mathrm{~mL}$ overnight cultures using a DNA extraction kit following the manufacture's instructions (Aidlab). Quantification and quality control of the genomic DNA were completed by using a Qubit fluorometer (Invitrogen, CA, USA) with Qubit dsDNA BR Assay kit and 0.7\% agarose gel electrophoresis with $\lambda$-Hind III digest DNA marker.

\section{Genome sequencing and assembly}

Complete genome sequencing was performed on an Illumina HiSeq 2500 system by constructing three DNA libraries (a paired-end library with insert size of $491 \mathrm{bp}$, and two mate pair libraries with insert sizes of 2.5 and $6.9 \mathrm{~kb}$ ). After filtering low quality and Illumina PCR adapter reads, a total of $1967 \mathrm{Mb}$ clean data were obtained from $2052 \mathrm{Mb}$ raw data. Subsequently, all reads data were denovo assembled into a circular contig with 259 folds of genomic coverage, using SOAPdenovo v.2.04 [17]. Detailed genome sequencing project information is shown in Table 2.

\section{Genome annotation}

Gene prediction was carried out by GeneMarkS v.4.6 [18]. Function annotation of predicted ORFs was performed based on a BLASTP search against NCBI nonredundant protein database and COG database. Transfer RNAs, rRNAs and sRNA were predicted using tRNAscan-SE v.1.31 with the bacterial model, RNAmmer v.1.2 and Rfam database v.9.1, respectively [19-21]. The CRISPRs were identified by using the CRISPR database [22]. The prediction of genes with signal peptides and transmembrane helices were performed by SignalP server v.4.1 [23] and TMHMM server v.2.0 [24], respectively. The secondary metabolism gene cluster was predicted according to the antiSMASH v.3.0 procedure [25].

\section{Genome properties}

The genome of $A$. humicireducens $\mathrm{SgZ}-5^{\mathrm{T}}$ comprises a circular chromosome of 3,181,617 bp and six circular plasmids, designated as pYZ1 (715,112 bp), pYZ2 (1,008,603 bp), pYZ3 (252,411 bp), pYZ4 (338,445 bp), pYZ5 (626,509 bp) and pYZ6 (711,682 bp) (Table 3). The total size of the genome is $6,834,379 \mathrm{bp}$, and the average GC content is $67.55 \%$. The genome contains 6054 genes with the total length of 5,902,731 bp, of which 5969 (98.6\%) are protein coding genes. There are
Table 3 Summary of genome: one chromosome and six plasmids

\begin{tabular}{lllll}
\hline Label & Size (bp) & Topology & INSDC identifier & RefSeq ID \\
\hline Chromosome & $3,181,617$ & Circular & CP015285.1 & NZ_CP015285.1 \\
pYZ1 & 715,112 & Circular & CP028902.1 & NA \\
pYZ2 & $1,008,603$ & Circular & CP028903.1 & NA \\
pYZ3 & 252,411 & Circular & CP028904.1 & NA \\
pYZ4 & 338,445 & Circular & CP028905.1 & NA \\
pYZ5 & 626,509 & Circular & CP028906.1 & NA \\
pYZ6 & 711,682 & Circular & CP028907.1 & NA \\
\hline
\end{tabular}

85 RNA genes (1.4\%), including 14 rRNA and 67 tRNA genes. A total of 4844 genes $(80.0 \%)$ have been assigned a predicted function while the rest have been designated as hypothetical proteins. Genome statistics are summarized in Table 4 and a graphical map is represented in Fig. 3. Furthermore, $4550(75.2 \%)$ genes were assigned to 21 COG functional categories. The distribution of genes into different COG functional categories is provided in Table 5. Six Azospirillum species genomes (including $A$. humicireducens) of characterized strains are compared in Table 6. Almost all of these Azospirillum genomes consisting of 6-8 replicons have the total size of 6.5-7.6 Mb and the average GC content of $67.5-70.7 \%$, and contain the total genes in the range of 5951 to 6982 $[3,6,26,27]$. Furthermore, the main features of A. humicireducens $\mathrm{SgZ}-5^{\mathrm{T}}$ genome are close to those of A. lipoferum 4B genome.

Table 4 Genome statistics of A. humicireducens SgZ- $5^{\top}$

\begin{tabular}{lll}
\hline Attribute & \multicolumn{2}{l}{ Genome (total) } \\
\cline { 2 - 3 } & Value & $\%$ of total \\
\hline Genome size (bp) & $6,834,379$ & 100.00 \\
DNA coding (bp) & $5,902,731$ & 86.37 \\
DNA G + C (bp) & $4,616,422$ & 67.55 \\
DNA scaffolds & 7 & \\
Total genes & 6054 & 100.00 \\
Protein coding genes & 5969 & 98.60 \\
RNA genes & 85 & 1.40 \\
rRNA genes & 14 & 0.23 \\
tRNA genes & 67 & 1.11 \\
Pseudo genes & 194 & 3.20 \\
Genes in internal clusters & NA & \\
Genes with function prediction & 4844 & 80.01 \\
Genes assigned to COGs & 4550 & 75.16 \\
Genes with signal peptides & 425 & 7.02 \\
Genes with transmembrane helices & 1022 & 16.88 \\
CRISPR repeats & 3 & \\
\hline
\end{tabular}




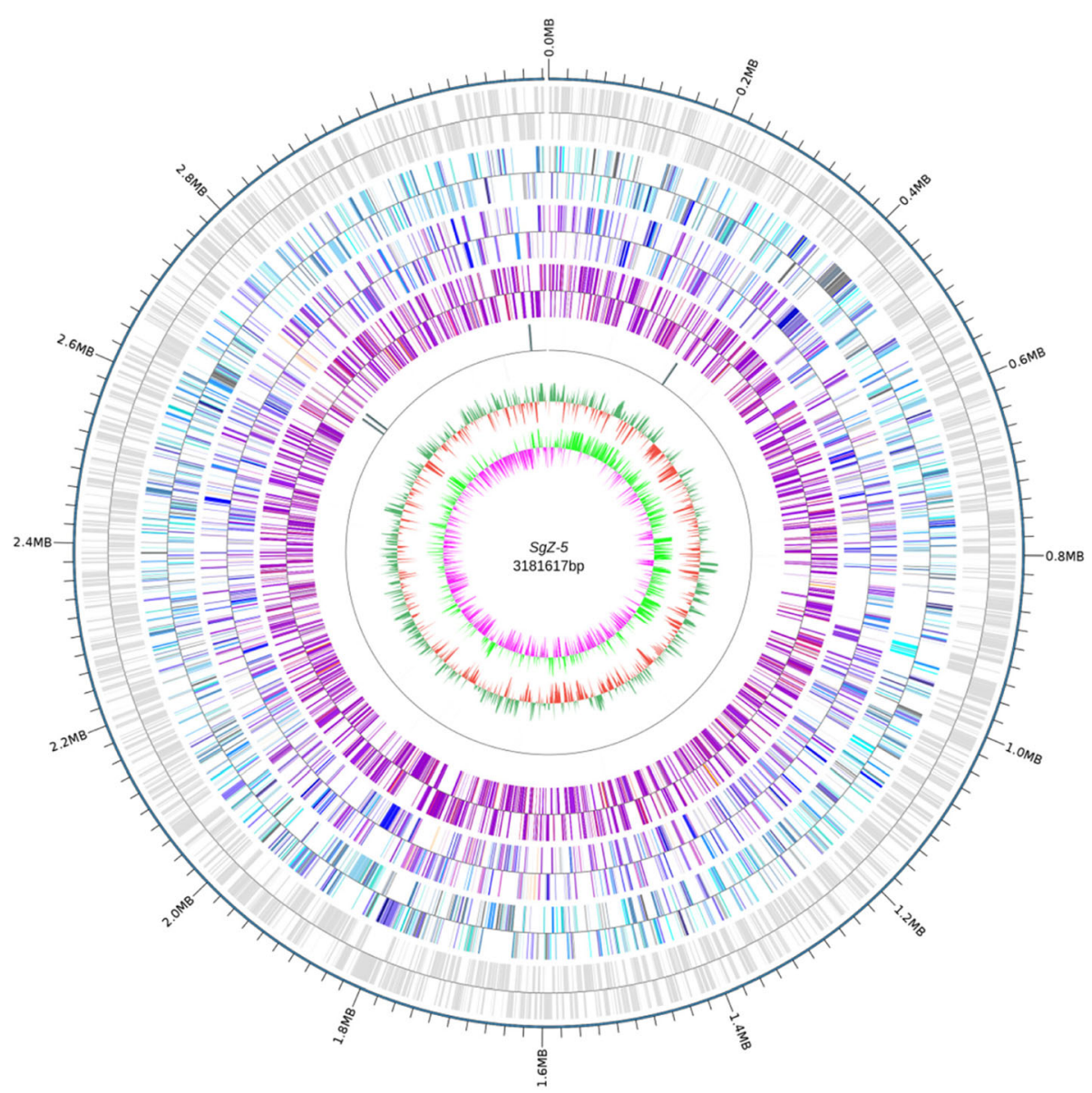

Fig. 3 Circular map of the chromosome of A. humicireducens SgZ-5T. From center to outside, circle 1 illustrates the GC skew. Circle 2 shows GC content (peaks out/inside the circle indicate values higher or lower than the average $\mathrm{G}+\mathrm{C}$ content, respectively). Circle 3 denotes ncRNA genes. Circles 4, 5 and 6 indicate the CDSs, colored according to COG, KEGG and GO categories, respectively. Circle 7 demonstrates the predicted protein-coding sequences

\section{Insights into the genome sequence}

Nitrogen fixation is the major proposed mechanism, by which Azospirillum affects plant growth [2, 4]. A complete set of genes encoding enzymes involved in nitrogen fixation was found in the genomic analysis of A. humicireducens $\operatorname{SgZ}^{-} 5^{\mathrm{T}}$ (Table 7). The main genes involved in this process are nif genes, of which nifDK genes (A6A40_02900 and A6A40_02895) annotated as nitrogenase molybdenum-iron proteins and nifH gene (A6A40_02905) encoding dinitrogenase reductase protein have been identified. In the upstream region of the nifHDK operon, we have found that nifEN genes (A6A40_02875 and A6A40_02870) involved in synthesis of the molybdenum-iron cofactor of nitrogenase are clustered into a single operon together with nif X (A6A40_02865). Furthermore, the genome of $A$. humicireducens $\mathrm{SgZ}-5^{\mathrm{T}}$ has nifUSVW genes (A6A40_02235, A6A40_02230, A6A40_ 02225 and A6A40_02215), which are separated from the structural nifENX operon by about $160 \mathrm{~kb}$.
Organization of the nitrogen fixation gene cluster in $A$. humicireducens $\mathrm{SgZ}-5^{\mathrm{T}}$ is presented in Fig. 4. Except for the separately transcribed nifA (A6A40_09040), nifB (A6A40_09050) and nifZ genes (A6A40_09070 and A6A40_09075), all the nif genes have resided in the nitrogen fixation gene cluster of $176.7 \mathrm{~kb}$. Besides, an operon containing fixABCX genes (A6A40_02185, A6A40_02190, A6A40_02195 and A6A40_02220) responsible for electron transfer to nitrogenase is located upstream of this gene cluster. Nevertheless, the fix $A B C X$ operon is generally regulated by a transcriptional activator NifA protein for all nitrogen-fixing bacteria in the genus Azospirillum studied so far [5]. Furthermore, draTG genes (A6A40_02920 and A6A40_02925) implicated in posttranslational regulatory process of nitrogenase activity were found in the downstream of and divergently oriented with respect to nifHDK genes. On the whole, the nitrogen fixation gene cluster of A. humicireducens SgZ- $5^{\mathrm{T}}$ was in agreement with that in A. brasilense, A. lipoferum and Azospirillum sp. 
Table 5 Number of genes associated with general COG functional categories

\begin{tabular}{|c|c|c|c|}
\hline Code & Value & $\%$ of total ${ }^{a}$ & Description \\
\hline J & 182 & 2.98 & Translation, ribosomal structure and biogenesis \\
\hline A & 0 & 0.00 & RNA processing and modification \\
\hline K & 357 & 5.85 & Transcription \\
\hline L & 175 & 2.87 & Replication, recombination and repair \\
\hline B & 1 & 0.02 & Chromatin structure and dynamics \\
\hline $\mathrm{D}$ & 38 & 0.62 & Cell cycle control, cell division, chromosome partitioning \\
\hline V & 80 & 1.31 & Defense mechanisms \\
\hline T & 338 & 5.54 & Signal transduction mechanisms \\
\hline M & 218 & 3.57 & Cell wall/membrane/envelope biogenesis \\
\hline N & 73 & 1.20 & Cell motility \\
\hline$U$ & 58 & 0.95 & Intracellular trafficking, secretion, and vesicular transport \\
\hline O & 162 & 2.65 & Posttranslational modification, protein turnover, chaperones \\
\hline C & 342 & 5.60 & Energy production and conversion \\
\hline G & 263 & 4.31 & Carbohydrate transport and metabolism \\
\hline $\mathrm{E}$ & 448 & 7.34 & Amino acid transport and metabolism \\
\hline F & 81 & 1.33 & Nucleotide transport and metabolism \\
\hline $\mathrm{H}$ & 160 & 2.62 & Coenzyme transport and metabolism \\
\hline I & 139 & 2.28 & Lipid transport and metabolism \\
\hline P & 333 & 5.45 & Inorganic ion transport and metabolism \\
\hline Q & 144 & 2.36 & Secondary metabolites biosynthesis, transport and catabolism \\
\hline $\mathrm{R}$ & 227 & 3.72 & General function prediction only \\
\hline S & 731 & 11.97 & Function unknown \\
\hline- & 1555 & 25.47 & Not in COGs \\
\hline
\end{tabular}

${ }^{a}$ The total is based on the total number of protein coding genes in the annotated genome

Table 6 Genome statistics comparison among characterized Azospirillum species ${ }^{a}$

\begin{tabular}{|c|c|c|c|c|c|c|c|c|}
\hline \multirow[t]{2}{*}{ Genome name } & \multicolumn{3}{|l|}{1} & \multirow{2}{*}{$\begin{array}{l}2 \\
4 B\end{array}$} & \multirow{2}{*}{$\begin{array}{l}3 \\
\text { DSM } 3675\end{array}$} & \multirow{2}{*}{$\begin{array}{l}4 \\
\text { BV-S }\end{array}$} & \multirow{2}{*}{$\begin{array}{l}5 \\
B 510\end{array}$} & \multirow{2}{*}{$\begin{array}{l}6 \\
\text { SgZ-5 }\end{array}$} \\
\hline & $\overline{S p} 7$ & Az39 & Sp245 & & & & & \\
\hline Genome size (Mb) & 6.6 & 7.4 & 7.5 & 6.8 & 6.5 & 7.6 & 7.6 & 6.8 \\
\hline Plasmids & 5 & 5 & 6 & 6 & NA & 7 & 6 & 6 \\
\hline $\mathrm{G}+\mathrm{C}$ content $(\%)$ & 68.3 & 68.5 & 68.5 & 67.7 & 70.7 & 68.2 & 67.6 & 67.5 \\
\hline Total genes & 5951 & 6713 & 6982 & 6137 & 5999 & 6684 & 6692 & 6054 \\
\hline Protein coding genes & 5828 & 6596 & 6882 & 6027 & 5925 & 6575 & 6582 & 5969 \\
\hline RNA genes & 123 & 117 & 100 & 110 & 74 & 109 & 110 & 85 \\
\hline rRNA genes & 29 & 26 & 15 & 26 & 11 & 26 & 26 & 14 \\
\hline tRNA genes & 90 & 87 & 81 & 80 & 59 & 79 & 80 & 67 \\
\hline Pseudogenes & 98 & 188 & 375 & 77 & 128 & 126 & 195 & 194 \\
\hline Frameshifted genes & 38 & 61 & 286 & 21 & 27 & 53 & 85 & 67 \\
\hline CRISPR & 2 & NA & NA & 3 & 4 & NA & 5 & 3 \\
\hline
\end{tabular}


Table 7 Genes of A. humicireducens SgZ- $5^{\top}$ involved in nitrogen fixation

\begin{tabular}{|c|c|c|c|}
\hline Locus Tag & Size/aa & Gene & Gene product \\
\hline A6A40_02185 & 852 & fixA & Electron transfer flavoprotein beta subunit \\
\hline A6A40_02190 & 1080 & $f i x B$ & Electron transfer flavoprotein alpha chain \\
\hline A6A40_02195 & 1302 & fixc & Flavoprotein-ubiquinone oxidoreductase \\
\hline A6A40_09085 & 210 & fixU & Nitrogen fixation protein \\
\hline A6A40_02200 & 285 & fix $X$ & Ferredoxin-like protein \\
\hline A6A40_09040 & 1866 & nifA & Nif-specific transcriptional activator \\
\hline A6A40_09050 & 1518 & nifB & Nitrogenase FeMo cofactor biosynthesis protein \\
\hline A6A40_02900 & 1440 & nifD & Nitrogenase molybdenum-iron protein alpha chain \\
\hline A6A40_02875 & 1407 & nifE & Nitrogenase molybdenum-cofactor biosynthesis protein \\
\hline A6A40_02905 & 897 & nifH & Nitrogenase iron protein \\
\hline A6A40_02895 & 1560 & nifk & Nitrogenase molybdenum-iron protein subunit beta \\
\hline A6A40_02870 & 1371 & $\operatorname{nifN}$ & Nitrogenase molybdenum-cofactor biosynthesis protein \\
\hline A6A40_02230 & 1206 & nifs & Nitrogenase metalloclusters biosynthesis protein \\
\hline A6A40_02235 & 924 & nifU & Iron-sulfur cluster assembly scaffold protein \\
\hline A6A40_02225 & 1122 & nifl & Homocitrate synthase \\
\hline A6A40_02215 & 336 & nifW & Nitrogenase-stabilizing/protective protein \\
\hline A6A40_02865 & 399 & nifX & Nitrogenase molybdenum-iron protein \\
\hline A6A40_09070 & 333 & nifZ & Nitrogenase P-cluster assembly \\
\hline A6A40_09075 & 306 & nifZ & Nitrogenase P-cluster assembly \\
\hline A6A40_02220 & 852 & CysE & Serine acetyltransferase \\
\hline A6A40_02925 & 909 & draG & ADP-ribosyl-[dinitrogen reductase] hydrolase \\
\hline A6A40_02920 & 891 & draT & ADP-ribosyl-[dinitrogenase reductase] transferase \\
\hline A6A40_07245 & 2847 & $g \ln D$ & [Protein-PII] uridylyltransferase \\
\hline A6A40_07685 & 339 & $g \ln B$ & Nitrogen regulatory protein P-\| \\
\hline A6A40_05220 & 1200 & $n t r B$ & Nitrogen regulation sensor histidine kinase \\
\hline A6A40_05215 & 1146 & $n \operatorname{trC}$ & Nitrogen regulation response regulator \\
\hline A6A40_05205 & 1401 & $n t r x$ & Sigma-54-dependent transcriptional regulator \\
\hline A6A40_05210 & 2319 & $n t r Y$ & Nitrogen regulation sensor histidine kinase \\
\hline
\end{tabular}

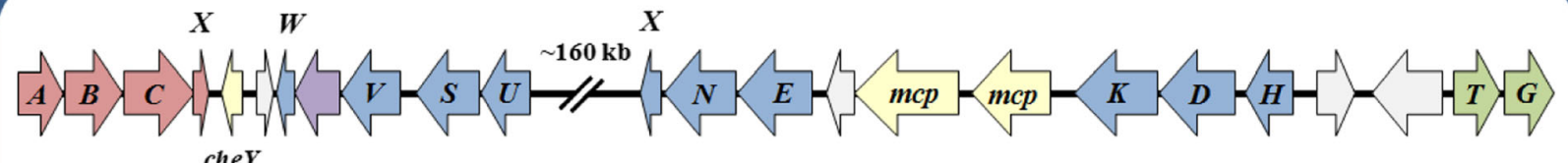

cheY

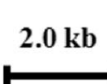

fix genes

nif genes

dra genes

cysE gene

\section{Not related to nitrogen fixtion}

\section{hypothetical genes}

Fig. 4 Organization of the nitrogen fixation gene cluster in A. humicireducens SgZ-5 ${ }^{\top}$. Arrows represent genes and their respective direction of transcription. Genes are colored as depicted in the lower box 
B510 [6, 26, 28, 29], suggesting that nitrogen fixation process demands the systematic action of various genes.

Since tryptophan is a main precursor for biosynthesis of IAA, a well-known phytohormone [30], the genes in $A$. humicireducens $\mathrm{SgZ}-5^{\mathrm{T}}$ related to the production of this amino acid have been analyzed (Additional file 2). The genome harbors three genes trpE, trpG and trpEG (A6A40_04380, A6A40_04655 and A6A40_05775), each encoding the key enzyme anthranilate synthase in tryptophan biosynthesis. Together with $\operatorname{trp} G$, the genes $\operatorname{trp} D$ (A6A40_04650) and trpC (A6A40_04645) form a gene cluster of $2.4 \mathrm{~kb}$. Except for anthranilate synthase, this trpGDC gene cluster encodes anthranilate phosphoribosyltransferase and indole-3-glycerol phosphate synthase, which plays a role in synthesis of tryptophan used in multiple biological processes including IAA biosynthesis [31]. The same trpGDC cluster was previously found in A. brasilense [32]. Although the ipdC gene, related to the indole-3-pyruvate pathway for the biosynthesis of IAA [30], was not discovered in the $A$. humicireducens $\mathrm{SgZ}-5^{\mathrm{T}}$ genome, alternative pathway might exist in $\mathrm{SgZ}-5^{\mathrm{T}}$. In the genome, A6A40_22745 and A6A40_22755 were assigned as candidates for iaaM and $i a a H$ genes, respectively. These two genes were also found in the Azospirillum sp. B510 genome, and are known to be involved in the IAM pathway for IAA biosynthesis by catalyzing the decarboxylation of tryptophan into IAM and the hydrolysis of IAM to produce IAA $[6,30]$.

The $A$. humicireducens $\operatorname{SgZ}-5^{\mathrm{T}}$ genome also contains a terpene gene cluster of $24.0 \mathrm{~kb}$ consisting of 23 genes (A6A40_04945, A6A40_04950, A6A40_04955, ..., A6A4 0_05055) (Additional file 3). This gene cluster encodes a series of proteins, which are involved in the biosynthesis of secondary metabolite production of terpenoid. Thereinto, A6A40_05010 was indentified as the crtB gene, encoding phytoene synthase involved in the biosynthesis of carotenoid. Similar genes in this gene cluster were previously observed in the A. lipoferum 4B genome [7, 26]. Furthermore, some phytohormones including gibberellins and abscisic acid with over 120 types found in plants, fungi, and bacteria, are synthesized through the terpenoid pathway [2]. Therefore, A. humicireducens SgZ-5 exhibits an attractive application as a PGPR likely harboring multiple PGPP in agriculture.

\section{Conclusion}

We report here an inventory of the genomic features of the nitrogen-fixing bacterium $A$. humicireducens $\mathrm{SgZ}-5^{\mathrm{T}}$. The genome sequence of strain $\mathrm{SgZ}-5^{\mathrm{T}}$ revealed further genetic elements involved in nitrogen fixation and its regulation, as well as in the production of phytohormones. We anticipate that knowledge of this genome will contribute to new insights into the mechanisms of plant growth stimulation through genomic comparisons among available complete genomes of Azospirillum strains.

\section{Additional files}

Additional file 1: Phylogenetic tree based on the partial nifH gene sequences showing the position of $A$. humicireducens $S g Z-5^{\top}$ relative to other species within the genus Azospirillum and related genus. The strains and their corresponding GenBank accession numbers of nifH gene were indicated in parentheses. The sequences were aligned using Clustal W and the neighbor-joining tree was constructed based on kimura 2-paramenter distance model by using MEGA 5 . Bootstrap values above $50 \%$ were obtained from 1000 bootstrap replications. Bar, 0.01 substitutions per nucleotide position. Leptospirillum ferriphilum YSKT was used as an

outgroup. (DOCX $64 \mathrm{~kb}$ )

Additional file 2: Genes of A. humicireducens $\mathrm{SgZ}-5^{\top}$ involved in biosynthesis of tryptophan. (DOCX $16 \mathrm{~kb}$ )

Additional file 3: Genes of $A$. humicireducens $S g Z-5^{\top}$ located in a terpene gene cluster. (DOCX $16 \mathrm{~kb})$

\section{Abbreviations}

AQDS: Anthraquinone-2, 6-disulfonate; IAA: Indole-3-acetic acid; IAM: Indole3-actamide; MFC: Microbial fuel cell; NA: Nutrient Agar; NB: Nutrient Broth; PGPP: Plant growth promoting properties; PGPR: Plant growth-promoting rhizobacteria

\section{Acknowledgments}

This work was supported by the Guangdong Academy of Sciences Funds for Innovation Driven Development, China (2017GDASCX-0409), the National Natural Science Foundation of China (41501546), the Guangdong Natural Science Foundation, China (2016A030313779), and the Science and Technology Planning Project of Guangdong, China (2017A030303057).

\section{Authors' contributions}

LZ and SZ conceived and designed the experiments. GY, YW and XL performed the experiments. $Z Y$ assembled and analysed genome. $Z Y$ and $L Z$ drafted the manuscript. GY and SZ revised the manuscript. All authors read and approved the final manuscript.

\section{Competing interests}

The authors declare that they have no competing interests.

\section{Publisher's Note}

Springer Nature remains neutral with regard to jurisdictional claims in published maps and institutional affiliations.

\section{Author details}

${ }^{1}$ Guangdong Key Laboratory of Agricultural Environment Pollution Integrated Control, Guangdong Institute of Eco-Environmental Science \& Technology, Guangzhou 510650, China. ${ }^{2}$ School of Environment, Guangdong Key Laboratory of Environmental Pollution and Health, Jinan University, Guangzhou 510632, China. ${ }^{3}$ Fujian Provincial Key Laboratory of Soil Environmental Health and Regulation, College of Resources and Environment, Fujian Agriculture and Forestry University, Fuzhou 350002, China.

Received: 26 February 2017 Accepted: 24 September 2018 Published online: 16 October 2018

References

1. Okon Y, Vanderleyden J. Root-associated Azospirillum species can stimulate plants. ASM News. 1997;63:366-70.

2. Bashan Y, De-Bashan LE. How the plant growth-promoting bacterium Azospirillum promotes plant growth-a critical assessment. Adv Agron. 2010; 108:77-136.

3. Kwak Y, Shin JH. First Azospirillum genome from aquatic environments: whole-genome sequence of Azospirillum thiophilum BV-ST, a novel diazotroph harboring a capacity of sulfur-chemolithotrophy from a sulfide spring. Mar Genomics. 2016;25:21-4.

4. Okon $Y$, Heytler PG, Hardy RWF. $N_{2}$ fixation by Azospirillum brasilense and its incorporation into host Setaria italica. Appl Environ Microbiol. 1983;46:694-7. 
5. Steenhoudt O, Vanderleyden J. Azospirillum, a free-living nitrogen-fixing bacterium closely associated with grasses: genetic, biochemical and ecological aspects. FEMS Microbiol Rev. 2000;24:487-506.

6. Kaneko T, Minamisawa K, Isawa T, Nakatsukasa H, Mitsui H, Kawaharada Y, et al. Complete genomic structure of the cultivated rice endophyte Azospirillum sp. B510. DNA Res. 2010;17:37-50.

7. Drogue B, Sanguin H, Borland S. Genome wide profiling of Azospirillum lipoferum $4 \mathrm{~B}$ gene expression during interaction with rice roots. FEMS Microbiol Ecol. 2014;87:543-55.

8. Tsavkelova EA, Klimova SY, Cherdyntseva TA, Netrusov Al. Microbial producers of plant growth stimulators and their practical use: a review. Appl Biochem Microbiol. 2006;42:117-26.

9. Sant'Anna FH, Almeida LGP, Cecagno R, Reolon LA, Siqueira FM, Machado MRS, et al. Genomic insights into the versatility of the plant growth-promoting bacterium Azospirillum amazonense. BMC Genomics. 2011;12:409.

10. Lin SY, Liu YC, Hameed A, Hsu YH, Huang H, Lai WA, et al. Azospirillum agricola sp. nov., a nitrogen-fixing species isolated from cultivated soil. Int J Syst Evol Microbiol. 2016;66:1453-8.

11. Zhou SG, Han LC, Wang YQ, Yang GQ, Zhuang L, Hu P. Azospirillum humicireducens sp. nov., a nitrogen-fixing bacterium isolated from a microbial fuel cell. Int J Syst Evol Microbiol. 2013;63:2618-24.

12. Tamura K, Dudley J, Nei M, Kumar S. MEGA4: molecular evolutionary genetic analysis (MEGA) software version 4.0. Mol Biol Evol. 2007:24:1596-9.

13. Nakade DB. Halotolerent Azospirillum lipoferum N-29 as a biofertilizer for saline soils. J Pure Appl Microbiol. 2013;7:795-801.

14. Tamilselvi S, Dutta A, Sindhu M. Azospirillum lipoferum and Pseudomonas fluorescens as effective biological agents for enhanced agro-productivity. Biosci J. 2016;32:670-83.

15. Raymond J, Siefert JL, Staples CR, Blankenship RE. The natural history of nitrogen fixation. Mol Biol Evol. 2004;21:541-54.

16. Field D, Garrity G, Gray T, Morrison N, Selengut J, Sterk P, et al. The minimum information about a genome sequence (MIGS) specification. Nat Biotechnol. 2008;26(5):541-7.

17. Luo R, Liu B, Xie Y, Li Z, Huang W, Yuan J, et al. SOAPdenovo2: an empirically improved memory-efficient short-read de novo assembler. GigaScience. 2012;1:18

18. Besemer J, Lomsadze A, Borodovsky M. GeneMarkS: a self-training method for prediction of gene starts in microbial genomes. Implications for finding sequence motifs in regulatory regions. Nucleic Acids Res. 2001;29:2607-18.

19. Lowe TM, Eddy SR. tRNAscan-SE: a program for improved detection of transfer RNA genes in genomic sequence. Nucleic Acids Res. 1997;25:955-64.

20. Lagesen K, Hallin P, Rodland EA, Staerfeldt HH, Rognes T, Ussery DW. RNAmmer: consistent and rapid annotation of ribosomal RNA genes. Nucleic Acids Res. 2007:35:3100-8.

21. Gardner PP, Daub J, Tate JG, Nawrocki EP, Kolbe DL, Lindgreen S, et al. Rfam: updates to the RNA families database. Nucleic Acids Res. 2009;37: D136-40.

22. Woese CR, Kandler O, Wheelis ML. Towards a natural system of organisms: proposal for the domains Archaea, Bacteria, and Eucarya. Proc Natl Acad Sci U S A. 1990;87(12):4576-9.

23. Petersen TN, Brunak S, von Heijne G, Nielsen H. Signal 4.0: discriminating signal peptides from transmembrane regions. Nat Methods. 2011;8:785-6.

24. Krogh A, Larsson B, von Heijne G, Sonnhammer ELL. Predicting transmembrane protein topology with a hidden Markov model application to complete genomes. J Mol Biol. 2001;305(3):567-80.

25. Weber T, Blin K, Duddela S, Krug D, Kim HU, Bruccoleri R, et al. antiSMASH 3. 0-a comprehensive resource for the genome mining of biosynthetic gene clusters. Nucleic Acids Res. 2015;43:W237-43.

26. Wisniewski-Dyé F, Borziak K, Khalsa-Moyers G, Alexandre G, Sukharnikov LO, Wuichet $\mathrm{K}$, et al. Azospirillum genomes reveal transition of Bacteria from aquatic to terrestrial environments. PLoS Genet. 2011;7(12):e1002430.

27. Rivera D, Revale S, Molina R, Gualpa J, Puente M, Maroniche G, et al. Complete genome sequence of the model rhizosphere strain Azospirillum brasilense az39, successfully applied in agriculture. Genome Announc. 2014; 2(4):e00683-14.

28. Fu HA, Fitzmaurice WP, Roberts GP, Burris RH. Cloning and expression of draTG genes from Azospirillum lipoferum. Gene. 1990;86:95-8.

29. Zhang Y, Burris RH, Roberts GP. Cloning, sequencing, mutagenesis, and functional characterization of draT and draG genes from Azospirillum brasilense. J Bacteriol. 1992;174:3364-9.
30. Spaepen S, Vanderleyden J, Remans R. Indole-3-acetic acid in microbial and microorganism-plant signaling. FEMS Microbiol Rev. 2007;31:425-48.

31. Kang SM, Asaf S, Kim SJ, Yun BW, Lee IJ. Complete genome sequence of plant growth-promoting bacterium Leifsonia xyli SE134, a possible gibberellin and auxin producer. J Biotechnol. 2016;239:34-8.

32. Zimmer W, Aparicio C, Elmerich C. Relationship between tryptophan biosynthesis and indole-3-acetic acid production in Azospirillum: identification and sequencing of a trpGDC cluster. Mol Gen Genet. 1991;229:41-51.

33. Garrity GM, Bell JA, Liburn T. Phylum XIV. Proteobacteria phyl. nov. In: Garrity GM, Brenner DJ, Krieg NR, Staley JT, editors. Bergey's manual of systematic bacteriology, volume 2, part B. 2nd ed. New York: Springer; 2005. p. 1

34. Garrity GM, Bell JA, Liburn T. Class I. Alphaproteobacteria class. nov. In: Brenner DJ, Krieg NR, Staley JT, Garrity GM, editors. Bergey's Manual of systematic bacteriology, volume 2, part C. 2nd ed. New York: Springer; 2005. p. 1.

35. Pfennig N, Trüper HG. Higher taxa of the phototrophic bacteria. Int J Syst Bacteriol. 1971;21:17-8.

36. Skerman VBD, McGowan V, Sneath PHA. Approved lists of bacterial names. Int J Syst Bacteriol. 1980;30:225-420.

37. Tarrand JJ, Krieg NR, Döbereiner J. A taxonomic study of the Spirillum lipoferum group, with descriptions of a new genus, Azospirillum gen. nov. and two species, Azospirillum lipoferum (Beijerinck) comb. nov. and Azospirillum brasilense sp. nov. Can J Microbiol. 1978:24:967-80.

38. List Editor. Validation list no. 2. Validation of the publication of new names and new combinations previously effectively published outside the IJSB. Int J Syst Bacteriol. 1979;29:79-80.

39. Ashburner M, Ball CA, Blake JA, Botstein D, Butler H, Cherry JM, et al. Gene ontology: tool for the unification of biology. The Gene Ontology Consortium. Nat Genet. 2000;25:25-9.

\section{Ready to submit your research? Choose BMC and benefit from:}

- fast, convenient online submission

- thorough peer review by experienced researchers in your field

- rapid publication on acceptance

- support for research data, including large and complex data types

- gold Open Access which fosters wider collaboration and increased citations

- maximum visibility for your research: over $100 \mathrm{M}$ website views per year

At BMC, research is always in progress.

Learn more biomedcentral.com/submissions 